\title{
Interactions Among Western Ragweed and Other Sandhills Species After Drought
}

\author{
Patrick E. Reece, ${ }^{1}$ Joe E. Brummer, ${ }^{2}$ Brian K. Northup, ${ }^{3}$ \\ Ann E. Koehler, ${ }^{4}$ and Lowell E. Moser ${ }^{5}$
}

\begin{abstract}
Authors are ${ }^{1}$ Professor, University of Nebraska, Panhandle Research and Extension Center, 4502 Ave I, Scottsbluff, NE 69361; ${ }^{2}$ Research Scientist, Colorado State University, Western Colorado Research Center, P.O. Box 598, Gunnison, CO 81230; ${ }^{3}$ Ecologist, USDA, Agricultural Research Service, Grazinglands Research Laboratory, 7207 W Cheyenne St, El Reno, OK 73036; ${ }^{4}$ Rangeland Ecology Research Analyst, University of Nebraska, Panhandle Research and Extension Center, 4502 Ave I, Scottsbluff, NE 69361; and 5 Professor, University of Nebraska, 352 Keim Hall, Lincoln, NE 68583.
\end{abstract}

\begin{abstract}
Interannual differences in yield and species composition of herbaceous vegetation on semiarid rangelands are common and often related to variations in precipitation regime. Interspecific interactions that occur after drought-induced population fluxes of western ragweed (Ambrosia psilostachya D.C.) were evaluated by removing western ragweed or associated species from $1-\mathrm{m}^{2}$ quadrats at weekly intervals beginning in early May, June, or July 1991 or 1992 on high-seral sandhills prairie in Nebraska. The composite of peak standing crops for ragweed and each group of associated species was $77 \%$ greater during May-October 1991

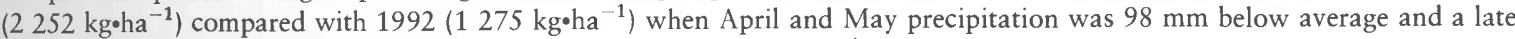
frost occurred. Mean levels of western ragweed herbage up to $436 \mathrm{~kg} \cdot \mathrm{ha}^{-1}$ had no effect on associated species in 1991 when above average precipitation occurred throughout the growing season. In contrast, when an unusually dry spring occurred in 1992 relatively small mean levels of ragweed $\left(189 \mathrm{~kg} \mathrm{ha}^{-1}\right)$ reduced end-of-season standing herbage of rhizomatous $\mathrm{C}_{4}$ grasses on control plots by about $21 \%\left(137 \mathrm{~kg}^{\circ} \mathrm{ha}^{-1}\right)$ with little effect on other associated species, regardless of when treatments were initiated. Within a given year, western ragweed density was seasonally constant, similar among treatments, and independent of preceding-year species composition. Severe defoliation of western ragweed had little effect on subsequent-year populations, indicating an ability to maintain primordia for several years with limited plant growth. Because western ragweed is not a strong competitor in the presence of yigorous graminoids, deferring use of June- or July-grazed pasture until after July in the subsequent year can minimize increases in western ragweed.
\end{abstract}

\section{Resumen}

Diferencias en el rendimiento interanual y la composición de las especies de vegetación herbáceo en praderas semi-aridas son común y frequentemente relacionados con la variedad del regimen de precipiación. Interrrelación interespecífica que ocurre despues del cambio continuamente provocado por la seguía en la ambrosía del oeste (Ambrosia psilostachya D.C.) fueron evaluadas con quitar la ambrosía del oeste y especies asociadas de 1-m en intervalos cada semana empezando en mayo, junio, o julio de 1991 o 1992 en praderas de alto crecimiento en Nebraska. El compuesto de cosechas de ambrosía en su punto máximo y cada grupo de especies asociadas fue $77 \%$ mayor durante mayo-octubre de 1991 (2,252 kg ha $\left.{ }^{-1}\right)$ comparado con 1992 (1,275 kg $\mathrm{ha}^{-1}$ ) cuando la precipitación en abril y mayo fue $98 \mathrm{~mm}$ menos del promedio y occurio una helada tardia. El promedio de ambrosía del oeste hasta $436 \mathrm{~kg} \mathrm{ha}^{-1}$ no tuvo ningun efecto en especies asociadas en 1991 cuando ocurrio precipitación más alla del promedio durante el periodo de crecimiento. En contraposición, cuando ocurrio una sequía durante la primavera en 1992 , relativamente pequeños niveles de ambrosía $\left(189 \mathrm{~kg} \mathrm{ha}^{-1}\right)$ redujeron la cosecha al fin de la temporada de zacate rizomato C4 en terrenos controlados por aproximadamente $21 \%\left(137 \mathrm{~kg} \mathrm{ha}^{-1}\right)$ con poco efecto en otras especies asociadas, sin tomar en cuenta cuando empezo el tratamiento. Durante cada año, la densidad de la ambrosia del oeste se mantuvo constante cada temporada, similar entre tratamientos, y independientemente de la composición de los años siguientes. Defoliación severa de ambrosía del oeste tuvo un pequepo efecto la populaciœn de los apos siguientes, indicando la capacidad de mantener el primigenio por varios abos con limitaciœn en el crecimiento de la planta. La ambrosía del oeste no tiene un competidor fuerte en la presencia de zacate vigoroso, el uso distinto en los pastos en junio o julio hasta despues de julio en los años siguientes puede desminuir el aumento de ambrosia del oeste.

Key Words: Ambrosia psilostachya, interspecific competition, seasonal herbage distribution, shoot density, subsequent-year effects

\section{Introduction}

Research was partially supported by funds provided through the Hatch Act and the Anna H. Elliott Fund, University of Nebraska Foundation. A contribution of the University of Nebraska Agricultural Research Division, Lincoln, Nebraska Journal Series No. 14287.

Correspondence: Dr Patrick E. Reece, University of Nebraska, Panhandle Research and Extension Center, 4502 Ave I, Scottsbluff, NE 69361.Email: preece@unl.edu

Manuscript received 17 October 2003; manuscript accepted 8 April 2004.
Western ragweed (Ambrosia psilostachya D.C.) is one of the most widely distributed (GPFA 1986) and abundant native forbs on rangelands in the Great Plains (Vermeire and Gillen 2000). It forms extensive clonal populations (Salzman 1985; Salzman and Parker 1985) with creeping and often deep 
Table 1. Codominant species of each category of species associated with western ragweed.

\begin{tabular}{|c|c|}
\hline \multicolumn{2}{|c|}{$\mathrm{C}_{4}$ rhizomatous grasses } \\
\hline Prairie sandreed & Calamovilfa Iongifolia (Hook.) Scribn. \\
\hline Sand bluestem & Andropogon hallii Hack. \\
\hline Switchgrass & Panicum virgatum $\mathrm{L}$. \\
\hline \multicolumn{2}{|c|}{$\mathrm{C}_{4}$ bunchgrasses } \\
\hline Little bluestem & Schizachyrium scoparium (Michx.) Nash \\
\hline Blue grama & Bouteloua gracilis (H.B.K.) Lag. ex Griffiths \\
\hline Sand dropseed & Sporobolus cryptandrus (Torr.) A. Gray \\
\hline \multicolumn{2}{|c|}{ Sedges } \\
\hline Sun sedge & Carex heliophila Mack. \\
\hline Schweinitz flatsedge & Cyperus schweinitzii Torr. \\
\hline \multicolumn{2}{|c|}{$\mathrm{C}_{3}$ grasses } \\
\hline Needle and thread & Stipa comata Trin. and Rupr. \\
\hline Prairie junegrass & Koeleria pyramidata (Lam.) Beaux. \\
\hline \multicolumn{2}{|c|}{ Other forbs } \\
\hline Stiff sunflower & $\begin{array}{l}\text { Helianthus ridgidus (Cass.) Desf. ssp. } \\
\text { subrhomboideus (Rydb.) Heiser }\end{array}$ \\
\hline Purple prairie clover & Dalea purpurea Vent. \\
\hline Narrowleaf puccoon & Lithospermum incisum Lehm. \\
\hline
\end{tabular}

rootstocks (Weaver 1958; GPFA 1986). Relative palatability of western ragweed herbage is low for cattle, bison, and deer (Fahnestock and Knapp 1993; Northup 1993; Fahnestock and Knapp 1994; Oretega et al 1997). However, seeds of western ragweed are considered an excellent protein source for gallinaceous bird species (Boren et al 1995). Additionally, over 130 insect species have been collected from western ragweed plants in North America (Goeden and Ricker 1985), which may enhance diet quality of small mammals and ground-nesting birds. Although increases in western ragweed may be desirable for wildlife, an abundance of this species in tallgrass or sandhills prairie is generally considered an indication of overgrazing (Vermeire and Gillen 2000). In spite of its potential impact, herbage relationships among this rhizomatous forb and associated species have not been quantified for semiarid sandhills prairies.

The Nebraska Sandhills encompass about 4.9 million contiguous hectares, and other similar sandhills prairies are widely distributed throughout the Great Plains. Population fluxes of western ragweed often occur between drought and the return of predrought conditions on high-seral sandhills prairie. Western ragweed appears to have the ability to rapidly respond to increased availability of soil water and nutrients resulting from drought and/or grazing-induced reductions in the vigor (Reece et al 1996) or tiller density (Reece et al 2002) of associated species. We hypothesized that western ragweed is a weak competitor with a disproportionately high potential for herbage production early in the growing season compared with associated species. Our objectives were to quantify interspecific herbage relationships and determine the role of shoot recruitment and growth potential in western ragweed herbage production and repopulation.

\section{Methods}

\section{Study Site}

This study was conducted on high-seral sandhills prairie (Table 1) at the University of Nebraska, Gudmundsen Sandhills Laboratory (GSL), near Whitman, Nebraska $\left(42^{\circ} 07^{\prime} \mathrm{N}, 101^{\circ} 43^{\prime} \mathrm{W}\right.$, elevation $1049 \mathrm{~m})$. All sites were in pastures used exclusively for dormant-season grazing (October-March) at moderate stocking rates (32 AUD.ha ${ }^{-1}$ ) since 1985. Soils are Valentine fine sands (mixed, mesic typic Ustipsamments).

Precipitation and air temperature data were measured and recorded by an automated weather station at the GSL headquarters. These data were used to determine plant-year precipitation, the moisture potentially available to plants during the growing season. It includes precipitation received during the preceding dormant season (October-March) plus that received during the current growing season (April-September). Plant year is identified by the year of the active growing season. The 15 -year average plant-year precipitation at GSL was $455 \mathrm{~mm}$.

\section{Data Collection}

This study was initiated the first week of May 1991. Eighteen $1-\mathrm{m}^{2}$ quadrats were randomly located and permanently marked in relatively homogeneous plant communities at 8 sites in each of 3 pastures. Nine quadrats were randomly selected for each treatment year, 1991 or 1992 , at each site. A $3 \times 3$ factorial array of defoliation treatments (removal of western ragweed, removal of associated species, or nonclipped control) and initial treatment application dates ( 10 May, 10 June, or 10 July) were randomly assigned to each set of 9 quadrats. Defoliation treatments were applied to the entire $1-\mathrm{m}^{2}$ area by clipping target species at ground level at weekly intervals throughout the growing season. Vegetation responses were measured in the interior $0.5-\mathrm{m}^{2}$ area of each quadrat to minimize the likelihood of clonal support from western ragweed plants outside the treatment area (Salzman 1985; Salzman and Parker 1985).

Western ragweed density was measured in the westernragweed-removal, associated-species-removal, and respective control plots when clipping was initiated in May, June, or July. End-of-season western ragweed density was measured on associated-species-removal and control plots in early October. Subsequent-year western ragweed density was measured in all quadrats in mid-June the year after treatments were applied.

Standing herbage of target species was collected on vegetation removal plots when defoliation treatments were initiated. Herbage removed at subsequent weekly clippings was discarded. End-of-season western ragweed herbage was measured on associated-species-removal and control plots in early October. End-of-season associated species herbage measurements were made on ragweed-removal and control plots. Herbage was oven dried at $60^{\circ} \mathrm{C}$ to a constant weight and weighed to estimate dry matter production. To estimate total annual production, we calculated the composite peak herbage by adding the peak standing herbage for western ragweed and each group of associated species (Table 1), regardless of when the peak occurred (eg, when defoliation treatments were initiated in May, June, or July, or during the end-of-season harvest in October). This value was used because herbage 


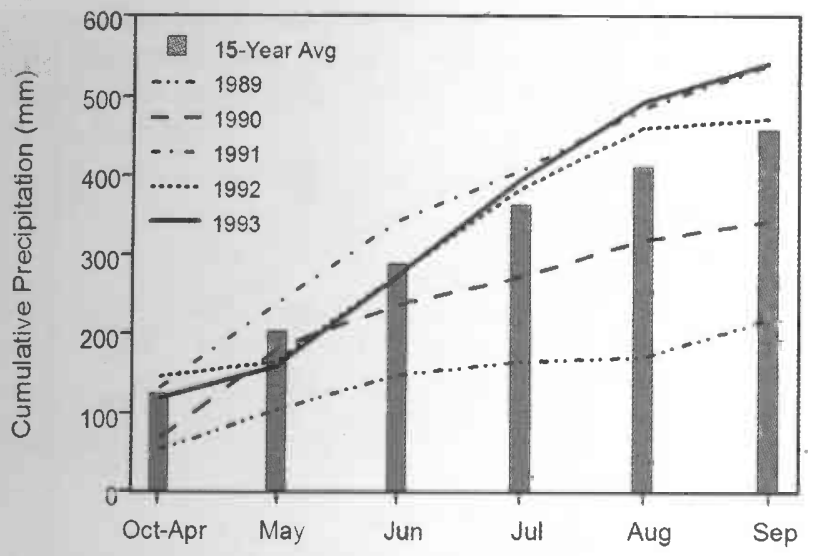

Figure 1. Cumulative plant-year (October-September) precipitation for the 1989-1993 growing seasons and the 15-year average at the Gudmundsen Sandhills Laboratory near Whitman, Nebraska.

production peaks at different times of the growing season for different species.

\section{Statistical Analysis}

Experimental units were $0.5-\mathrm{m}^{2}$ quadrats centrally placed in the $1 \times 1-\mathrm{m}$ treated areas. Data were analyzed as a randomized complete block using the general linear models procedure (SAS 2002). Level of probability selected for significance was $P \leq 0.05$. The least squares means procedure within SAS (2002) was used for mean separation. Regression equations (SAS 2002) describing the relationship between end-of-season western ragweed herbage and density were fit to experimental units within treatment dates and years. Equations describing the effect of initial date of associated species removal on endof-season standing crop of western ragweed were fit to pasture means within years (regression procedure, SAS 2002). The stepwise regression procedure (SAS 2002) was used to evaluate relationships between western ragweed density and precedingyear or current-year herbage produced by groups of associated species (Table 1). Stepwise regression was also used to determine if relationships occurred between subsequent-year western ragweed density and preceding-year ragweed density, mean shoot weight, or end-of-season herbage.

\section{Results and Discussion}

Based on field observations, relatively high frequencies of western ragweed occurred in the Nebraska Sandhills after prolonged drought from 1988 to 1990 , similar to observations reported by Bovey et al (1966) and Berg et al (1997). During this study, plant-year precipitation was $54 \%$ and $26 \%$ below average in 1989 and 1990, respectively, whereas it was $17 \%$ and 3\% above average in 1991 and 1992, respectively (Fig. 1). Western ragweed density on control plots ranged from 12 to $90 \cdot \mathrm{m}^{-2}$ in 1991 and 18 to $152 \cdot \mathrm{m}^{-2}$ in 1992 . End-of-season western ragweed herbage on control plots ranged from 36 to

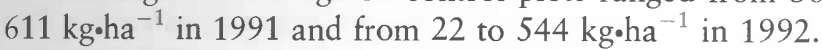

Composite peak herbage was $43 \%$ lower in 1992 (1 275

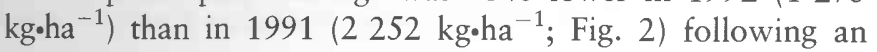

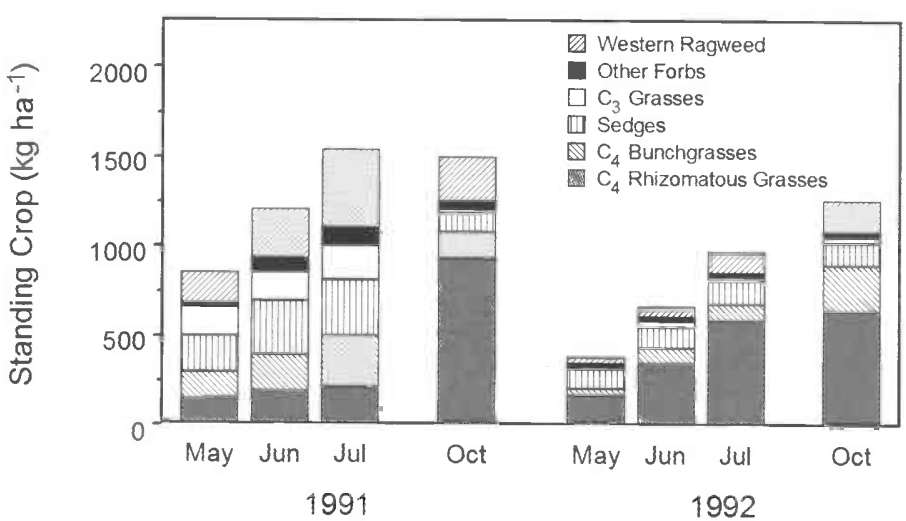

Figure 2. Seasonal patterns in standing herbage of western ragweed and associated species from initial harvests on vegetation removal plots initiated in early May, June, or July and end-of-season (early October) herbage harvested from control plots.

unusually dry April and May and a relatively late spring frost in 1992. Herbage production on sandhills prairies in this region is measurably greater in response to spring precipitation compared with summer precipitation (Dahl 1963). Precipitation during April and May 1991 was about $14 \%$ above the 15 -year average for GSL and $116 \mathrm{~mm}$ above April-May precipitation in 1992. Additionally, plants had 3 more weeks of uninterrupted spring growth in 1991 than in 1992 because of differences in the date of last frost (5 and 26 May, respectively).

\section{Seasonal Standing Crop Patterns}

During early May to early July, western ragweed and groups of associated species produced more herbage in 1991 compared with 1992, except for rhizomatous $\mathrm{C}_{4}$ grasses, which were about twice as productive in 1992 compared with 1991 (Table 2). All species, except $C_{3}$ grasses, contributed to increases in total standing crop from early May to early July 1991 (Fig. 2). Cool-season grass herbage was near peak standing crop in early May and remained relatively constant during May and June in both years. Increases in total herbage from May to July 1992 were primarily from rhizomatous $\mathrm{C}_{4}$ grasses (Fig. 2).

Western ragweed standing crop increased about 4.5 $\mathrm{kg} \cdot \mathrm{ha}^{-1} \cdot \mathrm{d}^{-1}$ from early May to early July in 1991 and about $1.3 \mathrm{~kg} \cdot \mathrm{ha}^{-1} \cdot \mathrm{d}^{-1}$ in 1992 (Fig. 2). However, mean density of

Table 2. Herbage (mean $\pm \mathrm{SE}$ ) produced by western ragweed and associated species averaged over May, June, and July sample dates for 1991 and 1992.

\begin{tabular}{lcc}
\hline Species & $1991^{1}\left(\mathrm{~kg} \cdot \mathrm{ha}^{-1}\right)$ & $1992^{1}\left(\mathrm{~kg} \cdot \mathrm{ha}^{-1}\right)$ \\
\hline Western ragweed & $294 \pm 16$ & $69 \pm 6$ \\
Other forbs & $69 \pm 4$ & $19 \pm 2$ \\
$\mathrm{C}_{3}$ grasses & $171 \pm 6$ & $26 \pm 4$ \\
Sedges & $274 \pm 10$ & $119 \pm 7$ \\
$\mathrm{C}_{4}$ bunchgrasses & $214 \pm 11$ & $73 \pm 6$ \\
$\mathrm{C}_{4}$ rhizomatous grasses & $180 \pm 6$ & $369 \pm 24$ \\
\hline
\end{tabular}

${ }^{1}$ Year effects were significant $(P<0.0001)$ for western ragweed and all groups of associated species. 
Table 3. End-of-season herbage of warm-season rhizomatous grasses for western ragweed removal and paired control treatments when removal started in early May, June, or July 1991 or 1992.

\begin{tabular}{|c|c|c|c|c|c|c|}
\hline \multirow[b]{2}{*}{ Month } & \multicolumn{3}{|c|}{$1991^{1}$} & \multicolumn{3}{|c|}{$1992^{1}$} \\
\hline & $\begin{array}{l}\text { Removal } \\
\left(\mathrm{kg}^{\prime} \mathrm{ha}^{-1}\right)\end{array}$ & $\begin{array}{c}\text { Control } \\
\left(\mathrm{kg}^{\circ} \mathrm{ha}^{-1}\right)\end{array}$ & $P$ & $\begin{array}{l}\text { Removal } \\
\left(\mathrm{kg}^{2} \mathrm{ha}^{-1}\right)\end{array}$ & $\begin{array}{c}\text { Control } \\
\left(\mathrm{kg}^{\circ} \mathrm{ha}^{-1}\right)\end{array}$ & $P$ \\
\hline May & 883 & 953 & 0.28 & 789 & 634 & 0.02 \\
\hline June & 1037 & 962 & 0.24 & 799 & 667 & 0.04 \\
\hline July & 856 & 860 & 0.96 & 759 & 634 & 0.05 \\
\hline
\end{tabular}

${ }^{1} Y$ ear by treatment interaction effects were significant, $P=0.01$. Standard errors ranged from $5 \%$ to $8 \%$ of the mean. Probability $(P)$ of differences between western ragweed removal treatments and paired controls refer to comparisons within years and months.

western ragweed was $42 \%$ greater $(P<0.0001)$ in 1992 $\left(71 \cdot \mathrm{m}^{-2}\right)$ compared with $1991\left(50 \cdot \mathrm{m}^{-2}\right)$. In contrast to seasonal population declines reported for tallgrass and mixed prairies (Vermeire and Gillen 2000), density of western ragweed in this study was relatively constant during the growing season and after killing frost in October. Consequently, seasonal increases in standing herbage of western ragweed were primarily the result of increases in mean shoot weight in both years.

Standing crop of western ragweed and most associated species declined from early July to October in 1991. In contrast, rhizomatous $\mathrm{C}_{4}$ grass herbage increased by about $710 \mathrm{~kg} \mathrm{ha}^{-1}$ during this period (Fig. 2), and its contribution to total standing crop increased from $14 \%$ to $62 \%$. The unusually large increase in rhizomatous $\mathrm{C}_{4}$ grass herbage corresponded to relatively high percentages of sand bluestem (Andropogan hallii Hack.) and prairie sandreed (Calamovilfa longifolia [Hook.] Scribn.) reproductive tillers, which are heavier than vegetative tillers (Hendrickson et al 1998; Reece et al 1999). In 1992, western ragweed and $\mathrm{C}_{4}$ bunchgrass herbage increased by $72 \%$ and $173 \%$, respectively, whereas little change occurred in other associated species from early July to October. Warm-season grasses accounted for about $72 \%$ of the herbage harvested in October in both years.

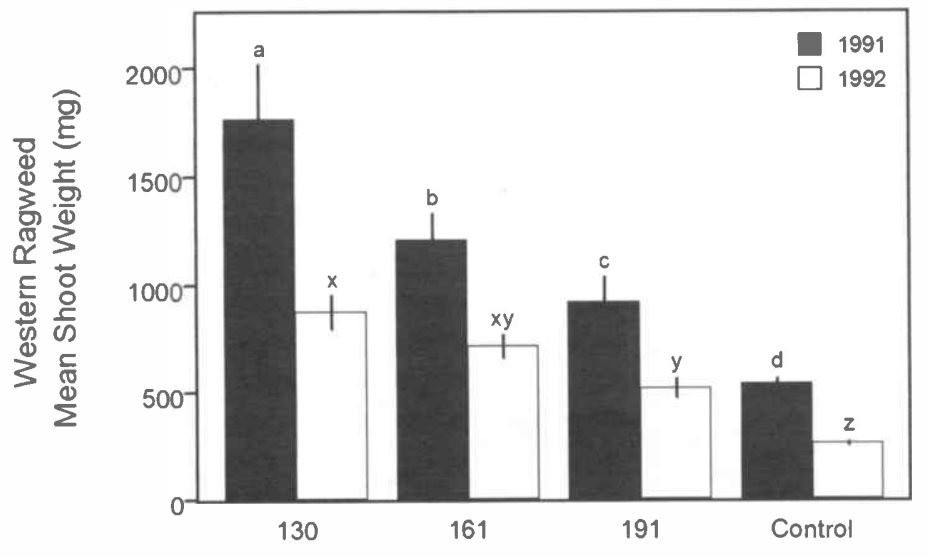

Start of Associated Species Removal (Day of Year)

Figure 3. End-of-season shoot weight (mean $\pm \mathrm{SE}$ ) of western ragweed for control and associated species removal treatments beginning on 3 dates in 1991 and 1992. Within years, means with the same letter are not different $(P>0.05)$.

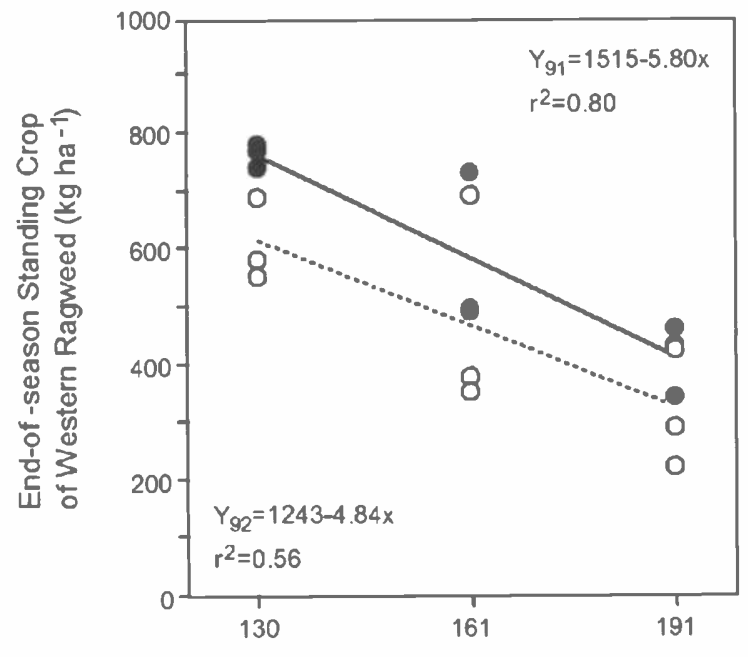

Start of Associated Species Removal (Day of Year)

Figure 4. Response of end-of-season standing crop of western ragweed to removal of associated species beginning on 3 dates in 1991 (filled circle) or 1992 (open circle).

\section{Effects of Western Ragweed Removal on Associated Species}

Mean levels of western ragweed herbage production up to $436 \mathrm{~kg} \mathrm{ha}^{-1}$ (Fig. 2) had no measurable effect on the yield of associated species in 1991 (Table 3) when above-average cumulative precipitation occurred throughout the growing season (Fig. 1). In contrast, when a dry spring occurred in 1992, relatively small amounts of western ragweed (189 $\mathrm{kg} \mathrm{ha}^{-1}$ ) on control plots (October) reduced end-of-season standing crop of rhizomatous $\mathrm{C}_{4}$ grasses by about $21 \%$ or $137 \mathrm{~kg} \cdot \mathrm{ha}^{-1}$ compared with western ragweed-removal treatments (Table 3).

Competition between western ragweed and associated species for limited soil water was most likely to occur during April and May of 1992 when precipitation was $98 \mathrm{~mm}$ below the 15 -year average. The relatively wide dispersion of sedges and $\mathrm{C}_{3}$ grasses in warm-season grass dominated communities and limited growth of $\mathrm{C}_{4}$ grasses in April and May may explain the lack of western ragweed effects on cool-season species in the sandhills. Tiller emergence of rhizomatous $\mathrm{C}_{4}$ grasses occurs primarily from April to mid-June. From $65 \%$ to $85 \%$ of prairie sandreed tillers emerge by the end of May (Cullan 1998; Hendrickson et al 2000; Reece et al 2002). If interspecific interference reduced tiller emergence and corresponding endof-season standing crop, yield responses of rhizomatous grasses, expressed as a percentage of paired controls (Table 3), should have declined as initial date of western ragweed removal was delayed. However, increases were relatively constant, ranging from $20 \%$ to $24 \%$ of paired controls, indicating measurable competitive effects did not occur until after 10 July. The apparent lack of effect of a dry spring on tiller emergence is consistent with a concurrent study at GSL in which rate of prairie sandreed tiller emergence and tiller number were poorly correlated with short- and long-term precipitation totals (Hendrickson et al 2000). 
Table 4. Linear relationship $(y=a+b x)$ between end-of-season western ragweed herbage $\left(\mathrm{kg} \cdot \mathrm{ha}^{-1}\right)$ and density $\left(\mathrm{No} \cdot \mathrm{m}^{-2}\right)$ in 1991 and 1992, with and without removal of associated species near Whitman, Nebraska.

\begin{tabular}{lrrrrrrrr}
\hline $\begin{array}{l}\text { Associated } \\
\text { Species }\end{array}$ & & \multicolumn{3}{c}{$1991^{1}$} & & \multicolumn{3}{c}{$1992^{1}$} \\
\cline { 3 - 4 } \cline { 7 - 9 } removal & $n$ & $a$ & $b \pm$ SE & $r^{2}$ & & $a$ & $b \pm$ SE & $r^{2}$ \\
\hline June & 24 & 184 & $6.5 \pm 1.6$ & 0.45 & & 141 & $4.6 \pm 0.9$ & 0.57 \\
July & 24 & 149 & $5.2 \pm 1.2$ & 0.48 & & 64 & $4.0 \pm 0.8$ & 0.51 \\
Control & 72 & 69 & $3.7 \pm 0.5$ & 0.40 & & -27 & $3.1 \pm 0.3$ & 0.66 \\
\hline
\end{tabular}

${ }^{1}$ All regression equations are significant, $P \leq 0.01$.

Competitive effects of western ragweed that occurred after 10 July may have been linked to epic events of tiller mortality that are common in rhizomatous graminoids during the growing season (Callaghan 1976; de Kroon et al 1992; Reece et al 2002). For example, Reece et al (2002) found that under relatively dry conditions, densities of prairie sandreed tillers declined $25 \%-64 \%$ during July or August. Mortality primarily occurs in small tillers that may be more susceptible to interspecific interference. Above average precipitation from June through August 1992 may not have eliminated the potential for competition for soil water given the low water holding capacity of sandy soils and relatively large amounts of $\mathrm{C}_{4}$ grass leaf area in July and August. The inability of rhizomatous $\mathrm{C}_{4}$ grasses to compensate for competitive effects when above average precipitation occurred during July and August 1992 suggests that herbage production potential was reduced, perhaps because of increased rates of tiller mortality during the summer.

\section{Effects of Associated Species Removal on Western Ragweed}

Associated species accounted for $72 \%-81 \%$ of the standing crop from May to July 1991 and $89 \%-91 \%$ of standing crop from May to July 1992 (Fig. 2). Western ragweed biomass increased in response to removal of associated vegetation (Fig. 3). Complete defoliation of associated species at weekly intervals may have increased the availability of soil water and nutrients, thereby reducing any effects of interspecific competition on western ragweed. Delaying removal of associated species (ie, release from interspecific competition) decreased western ragweed herbage at constant and similar rates in both years (Fig. $4 ; P>0.05$ ).

Yield response of western ragweed to removal of associated species in May, June, or July provided insight into how timing of summer grazing may affect herbage production by western ragweed. Mean end-of-season ragweed herbage on control plots

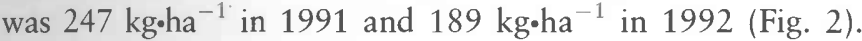
Based on the extrapolation of the regression lines in Fig. 4, severe defoliation of associated species after July would cause little or no increase in current-year western ragweed herbage.

Removal of associated species had no effect on ragweed density during the current growing season. Within a given year, western ragweed density accounted for $40 \%-48 \%$ of the variation in end-of-season ragweed standing crop in 1991 and $51 \%-66 \%$ of the variation in 1992 on control plots and on June or July associated-species-removal plots (Table 4). Progressively larger intercept and slope coefficients (Table 4) when associated

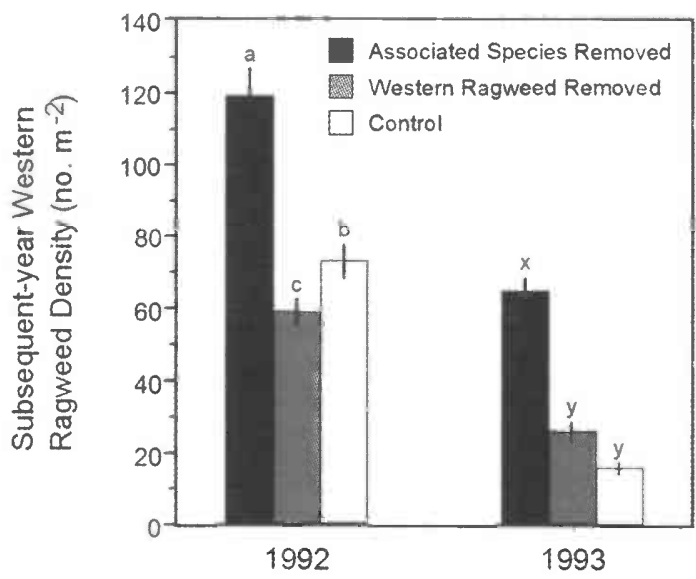

Figure 5. Subsequent-year western ragweed densities (mean $\pm \mathrm{SE}$ ) in mid-June 1992 and 1993, about 1 year after treatments were applied in 1991 or 1992, respectively. Data for the 3 treatment initiation dates did not differ $(P>0.05)$ and were pooled. Within years, means with the same letter are not different $(P>0.05)$.

species were removed earlier corresponded to increases in mean western ragweed shoot weights (Fig. 3). End-of-season western ragweed herbage was poorly correlated $\left(r^{2}<0.25\right)$ with density on May removal plots because some ragweed shoots grew disproportionately large. After removal of associated species in May, mean weight of western ragweed shoots on individual plots ranged from 641-5 $888 \mathrm{mg}$ in 1991 and 366$1934 \mathrm{mg}$ in 1992.

During a concurrent study at GSL (Brummer et al 1994), increases in western ragweed density and herbage production corresponded to declines in total organic reserves of prairie sandreed and sand bluestem in paddocks grazed heavily during July or multiple times during June, July, and/or August 19881991 (Reece et al 1996). However, total organic reserves of the grass species in dormant-season grazed paddocks were similar to nongrazed paddocks, indicating that drought-induced increases in western ragweed were primarily the result of reduced basal area of grasses (Reece et al 2002), rather than vigor.

\section{Subsequent-year Western Ragweed Density}

Large increases in herbage production by western ragweed generally preceded increases in subsequent-year western ragweed densities. Removal of associated species increased subsequent-year western ragweed densities by $59 \%$ in 1992 and $306 \%$ in 1993 compared with control plots (Fig. 5). However, posttreatment populations of individual clones were not clearly related $\left(r^{2}<0.25\right)$ to preceding-year species composition. Other factors may have contributed to this apparent lack of relationship. For example, phytophagous insects lay more eggs on large compared with small western ragweed plants (Reznik 1985), possibly impacting their subsequent contribution to repopulation. Although not measured, probable micro-environmental modifications included increased exposure to sunlight, warmer soil temperatures, and greater variation in diurnal air and soil temperature patterns. Wan et al (2002) reported progressive and relatively large annual increases in the density of western ragweed in year-long artificially warmed tallgrass prairie in Oklahoma. 
Without damaging plants, it was not possible to determine if shoots originated from rhizomes or seeds. However, vegetatively propagated clones share the same genetic material and are likely to be more uniform than plants produced from seed. In this study plots were widely distributed over 24 sites, yet within plots initial western ragweed densities and plant heights were relatively uniform. This suggests that most repopulation was from buds supported by a network of rhizomes (Salzman 1985; Salzman and Parker 1985). The similarity of posttreatment populations on control and ragweed-removal plots, where seed production was eliminated, supports this interpretation. Additionally, viable western ragweed seed was not observed in extensive seedbank surveys at GSL in 1990 and 1991 (Pérez et al 1998). They suggested that absence of viable seeds for many species may have resulted from reduced seed rain caused by prolonged drought and/or seed predation by mammals, birds, and/or granivorous invertebrates. Pérez et al (1998) reported limited occurrence of large seeded species in the seedbank and relatively high percentages of damaged seed in all collections.

The ability of western ragweed to produce densities similar to control plots after complete defoliation (Fig. 5) indicated this species can maintain primordia for at least 2 years with limited plant growth. Selective defoliation of this species by phytophagous insects used for biological control (Goeden and Ricker 1985) may be required for several years before declines in ragweed populations would be expected.

\section{Management Considerations}

Relatively low palatability, high potential for spring growth, and the ability to maintain primordia when herbage production is limited make western ragweed ecologically valuable for stabilizing sandhills prairie when drought and/or overgrazing occur. As an indigenous forb, western ragweed and associated species were in dynamic equilibrium on the high-seral sandhills prairie sites in this study. Relatively low shoot weights of western ragweed on control plots compared with the robust shoots that developed when associated species were removed clearly indicated the competitive inferiority of western ragweed in the presence of vigorous graminoids.

The competitive effect of western ragweed on rhizomatous $\mathrm{C}_{4}$ grasses after an unusually dry spring in 1992 was unexpected because these grasses are traditionally considered relatively drought tolerant. Additionally, vigor of rhizomatous grasses should have been relatively high because pastures were grazed only after killing frost for 7 years (Reece et al 1996). The majority of western ragweed shoots tend to develop in microsites that are relatively favorable for plant growth (Salzman 1985; Salzman and Parker 1985). The size and number of favorable microsites probably increased because of droughtinduced mortality in graminoids that occurred before our study was initiated. Shoots of western ragweed were most abundant in openings between bunchgrasses where rhizomatous $\mathrm{C}_{4}$ grass tillers were often in close proximity.

Economic and ecological thresholds for western ragweed on semiarid sandhills prairie appear to be inseparable from precipitation regime and grazing history. Defining thresholds strictly by shoot density or standing crop of western ragweed would be unreliable. Lack of competitive effects from western ragweed when above average precipitation occurred in this and other studies (Launchbaugh 1967; Vermeire and Gillen 2000) indicated economic thresholds for control of western ragweed have limited utility. Yield responses of graminoids to western ragweed control on semiarid, mid- to high-seral sandhills prairie are likely to be inconsistent and too small to recover the costs of chemical control.

Increases in subsequent-year western ragweed populations are most likely to occur on summer-grazed pastures compared with nongrazed (Gillen et al 1991) or dormant-season-grazed pastures (Brummer et al 1994). Heavy grazing during July is most likely to reduce vigor of dominant grasses (Reece et al 1996), and the regrowth potential of graminoids is limited after July (Reece et al 2001). If increases in subsequent-year density of western ragweed are linked to microenvironmental increases in temperature (Wan et al 2002), management practices that maintain uniformly distributed residual herbage may limit population increases. Reducing stocking rates and/or periodically deferring grazing until after killing frost in the fall will increase residual herbage and enhance the vigor of palatable species (Reece et al 1996).

\section{Acknowledgments}

The authors would like to thank Gordon Moeller and Bryan Hurst for technical assistance and Sharon Holman for preparation of the manuscript. We appreciate the numerous constructive comments by R.L. Gillen and 2 anonymous reviewers.

\section{Literature Cited}

Berg, W. A., J. A. Bradford, and P. L. Sims. 1997. Long-term soil nitrogen and vegetation change on sandhill rangeland. Journal of Range Management 50:482-486.

Boren, J. C., R. L. Lochmiller, D. M. Leslie, JR., and D. M. Engle. 1995. Amino acid concentrations in seed of preferred forages of bobwhites. Journal of Range Management 48:141-144.

Bovey, R. W., M. K. McCARTY, And F. S. Davis. 1966. Perennial ragweed on western Nebraska rangeland. Journal of Range Management 19:220-222.

Brummer, J. E., P. E. Reece, J. T. Nichols, and R. K. Engel. 1994. Western ragweed response to date and frequency of grazing sandhills vegetation. Society for Range Management Abstracts for Annual Meetings 47:63.

Callaghan, T. V. 1976. Growth and population dynamics of Carex bigelowii in an alpine environment: strategies of growth and population dynamics of tundra plants. Oikos 27:402-413.

CULLAN, A. P. 1998. Grazing date by stocking rate effects on prairie sandreed [MS thesis]. Lincoln, NE: University of Nebraska. $69 \mathrm{p}$.

DAHL, B. E. 1963. Soil moisture as a predictive index to forage yield for the sandhills range type. Journal of Range Management 16:128-132.

de Kroon, H., T. Hara, and R. Kwant. 1992. Size hierarchies of shoots and clones in clonal herb monoculture: do clonal and non-clonal plants compete differently? Oikos 63:410-419.

Fahnestock, J. T., AND A. K. KnAPp. 1993. Water relations and growth of tallgrass prairie forbs in response to selective grass herbivory by bison. International Journal of Plant Science 154:432-440.

Fahnestock, J. T., and A. K. Knapp. 1994. Plant response to selective grazing by bison: interactions between light, herbivory and water stress. Vegetation 115:123-131.

Gillen, R. L., F. T. McCollum, M. E. Hodges, J. E. Brummer, and K. W. Tate. 1991. Plant community responses to short duration grazing in tallgrass praine. Journal of Range Management 44:124-128.

Goeden, R. D., AND D. W. Ricker. 1985. The life history of Ophraella notulata (F.) on western ragweed, Ambrosia psilostachya De Candolle, in southern California (Coleoptera:Chrysomelidae). Pan-Pacific Entomologist 61:32-37. 
Great Plains Flora Association (GPFA). 1986. Flora of the Great Plains. Lawrence, KS: University Press of Kansas. 1392 p.

Henorickson, J. R., L. E. Moser, K. J. Moore, and S. S. Waller. 1998. Morphological development of 2 warm-season grasses in the Nebraska Sandhills. Journal of Range Management 51:456-462.

Hendaickson, J. R., L. E. Moser, and P. E. Reece. 2000. Tiller recruitment patterns and biennial tiller production in prairie sandreed. Journal of Range Management 53:537-543.

LaunCHBAUGH, J. L. 1967. Vegetation relationships associated with intensity of summer grazing on a clay upland range site in the Kansas 20 to 24 inch precipitation zone. Kansas Agricultural Experiment Station Bulletin No. 154. Manhattan, KS

NoRTHup, B. K. 1993. Utilization of native forages of the Nebraska Sandhills by yearling cattle [PhD dissertation]. Lincoln, NE: University of Nebraska. 328 p.

Ortega, I. M., S. Soltero-Gardea, F. C. Bryant, and D. L. Drawe. 1997. Evaluating grazing strategies for cattle: deer forage dynamics. Journal of Range Management 50:615-621.

Pérez, C. J., S. S. Waller, L. E. Moser, J. L. Stubbendieck, and A. A. Steuter. 1998. Seedbank characteristics of a Nebraska Sandhills prairie. Journal of Range Management 51:55-62.

Reece, P. E., J. E. Brummer, R. K. Engle, and B. K. Northup. 1996. Grazing date and frequency effects on prairie sandreed and sand bluestem. Journal of Range Management 49:112-116.

ReEce, P. E., T. L. Holman, And K. J. Moore. 1999. Late-summer forage on prairie sandreed dominated rangeland after spring defoliation. Journal of Range Management 52:228-234.

Reece, P. E., J. S. Nixon, L. E. Moser, and S. S. Waller. 2002. Seasonal dynamics of prairie sandreed rhizome development. Journal of Range Management 55: 182-187.

Reece, P. E., J. D. Volesky, and W. H. SсhaCht. 2001. Cover for wildlife after summer grazing on sandhills rangeland. Journal of Range Management 54: 126-131.

REZNIK, S. Y. 1985. Factors of oviposition selectivity in Zygogramma suturalis (Coleoptera, Chrysomelidae). Zoologicheskii Zhurnal 64:234-244.

Salzman, A. G. 1985. Habitat selection in a clonal plant. Science 228:603-604.

Salzman, A. G., and M. A. Parker. 1985. Neighbors ameliorate local salinity stress for a rhizomatous plant in a heterogeneous environment. Oecologia 65:273277.

SAS. 2002. SAS Online Doc®. Version 8. Cary, NC: SAS Institute, Inc.

Vermeire, L. T., AND R. L. Gillen. 2000. Western ragweed effects on herbaceous standing crop in Great Plains grasslands. Journal of Range Management 53: 335-341.

Wan, S., T. Yuan, S. Bowdish, L. Wallace, S. D. Russell, and Y. Luo. 2002. Response of an allergenic species, Ambrosia psilostachya (Asteraceae), to experimental warming and clipping: implications for public health. American Journal of Botany 89:1843-1846.

Weaver, J. E. 1958. Classification of root systems of forbs of grassland and consideration of their significance. Ecology 39:393-401. 